\title{
Surveillance Sounds of Bugis as the Austronesian Language family
}

\author{
Johar Amir \\ Universitas Negeri Makassar \\ Makassar, Indonesia \\ johar.amir.unm@gmail.com
}

\author{
Ambo Dalle \\ Universitas Negeri Makassar \\ Makassar, Indonesia \\ ambodalle1959@gmail.com
}

\begin{abstract}
This study aimed to describe the language sounds Bugis. In Proto Austronesian phonology of South Sulawesi, there are 6 (six) vowel phonemes and 18 consonant phonemes. The data in this study is the language sounds Bugis (realized in the form of the word) is absorbed from Indonesian. Sources of data in the study are the Bugis community residing in Bone regency. The data collection techniques are methods refer to the advanced techniques refer to techniques involved capably, recording technique, and technical notes. Also, it is also used proficient method with advanced technique, fishing techniques and advanced engineering techniques in the form of a conversation semuka, record, and note, As well as technical documentation. The results showed: (1) phonemes / $\mathrm{p} / \mathrm{g} / \mathrm{t} / \mathrm{l} / \mathrm{d} /$, and / $\mathrm{k} /$ at the end of words in Indonesian turn into glottal / $q$ / when absorbed into the Bugis language. Likewise, the phoneme / s / and / 1 / sounds turn into glottal / $q$ /. Only phoneme / s / and / 1 / phonemes have additional. (2) phoneme / $/$ / At the beginning of Indonesian syllables turned into sound geminasi when absorbed into the Bugis language. (3) nasal phonemes / $\mathrm{m} /$ and $/ \mathrm{n} /$ in Indonesian turn into phonemes nasal / $\mathrm{g} /$ when absorbed into the Bugis language. (4) nasal phoneme / $/$ / in Indonesian transformed into phoneme / a / when absorbed into the Bugis language. (5) phoneme / b / in Indonesian transformed into phoneme / w / when absorbed into the Bugis language. (6) phoneme / $z /$ in Indonesian turn into phonemes / $\mathrm{s} /$ when absorbed into the Bugis language. (7) The phoneme / $\mathrm{h} /$ at the beginning of words in Indonesian melted when absorbed into the Bugis language. The conclusion of this study is phonemes Bugis have variations in sound when absorbing the words of Indonesian.
\end{abstract} family

Keywords—search; sound; Bugis language; the Austronesian

\section{INTRODUCTION}

The Indonesian nation consists of various tribes that stretch from Sabang to Merauke. The diversity of tribe's linguistically different in any locations. There are 742 regional languages, 737 of which are still actively spoken Indonesian and regional languages [1]. It is included in the Austronesian family, more specifically, the regional languages in South Sulawesi included in the Austronesian group Southwestern. Austronesian language family is unique in its linguistic system, including Bugis language [2].

The sound system in Bugis is unique when compared to other languages. The author of this study compared the noise in Indonesian with the sound system in Bugis language [3].
There are systematic changes that occur from Indonesian sounds into audio Bugis language. For example, the sound / b / in the word / 'beras' / become / w / a / b /, in Bugis word / were / and / berre /. This is caused by the sound / w / and / b / phoneme correspondence with proto-Austronesian languagesespecially in South Sulawesi. There are many other changes other sounds described in this paper, such as the removal and addition of phonemes in Bugis [4].

\section{RESEARCH METHOD}

This research is qualitative. The data language in this study was obtained using advanced techniques refer to involved skilled, recording technique, and technique note. Also, it is also used methods proficient with advanced technique, fishing techniques and advanced engineering techniques in the form of a conversation, record, and note. As well as design documentation, Source of data in this research, are people who become an informant of Bugis Bone and Bugis language dictionary. In this study, there are three kinds' steps. (1) The provision of data, (2) analysis of data, and (3) the presentation of the results of the data analysis. The data collected in this study were analyzed using a unified method, and various techniques are adapted to the character data have been obtained in the field [5]

\section{DiscUSSION}

The sound of noise in the Bugis language

1. Phoneme / p / in Indonesian turn into glottal / $q$ / in Bugis Example:

/Closed/ $\rightarrow$ / Tutuq /

/envelope/ $\rightarrow$ / Ampəloq /

/roof/ $\rightarrow$ / Atəq /

/stage/ $\rightarrow$ / Tahaq /

Based on the examples listed in the data (1), the phoneme / $\mathrm{p} /$ at the end of words in Indonesian when absorbed into the language of the Bugis turned into glottal /q/. There is no sound / p / at the end of a word in Bugis. Likewise in South Sulawesi Proto.

2. Phoneme / $\mathrm{t} /$ in Indonesian turn into glottal / $\mathrm{q} /$ in Bugis Example: 


$$
\begin{array}{ll}
\text { /Graduation / } \rightarrow \text { / Təmməq / } \\
\text { /four/ } & \rightarrow \text { / Oppaq / } \\
\text { /folding/ } & \rightarrow \text { / Ləppəq / } \\
\text { /Tendon / } & \rightarrow \text { / Urəq / }
\end{array}
$$

Phoneme / $\mathrm{t} /$ at the end of words in Indonesian when absorbed into the language of the Bugis turned into a glottal stop / q /. This is in accordance with the proto South Sulawesi, because in Bugis there is no phoneme / $\mathrm{t} /$ at the end of the word.

3. Phoneme / s / at the end of words in Indonesian turn into glottal / q / in Bugis

Example:

$$
\begin{array}{ll}
\text { /thin/ } & \rightarrow \text { / Nipiq / } \\
\text { /ice/ } \rightarrow \text { / Esəq / } \\
\text { /fan/ } & \rightarrow \text { / Kipasaq / } \\
\text { /line/ } & \rightarrow \text { / Garisiq / }
\end{array}
$$

Likewise with the phoneme / s / at the end of words in Indonesian turn into glottal stop / q / when absorbed into the Bugis language. Unlike the phoneme / p / instantly transformed into glottal phoneme / $\mathrm{s} /$ has the addition of vocal sounds to the vowel before. It can be seen in the data (3) because in Bugis there is no phoneme / $\mathrm{s} /$ at the end of a word.

4. Phoneme $/ 1 /$ at the end of words in Indonesian turn into glottal / q / in Bugis

Example:

$$
\begin{array}{ll}
\text { /bottle/ } & \rightarrow \text { / Botoloq / } \\
\text { /bare/ } & \rightarrow \text { / Gunduluq / } \\
\text { /Deny / } & \rightarrow \text { / Sakkaq / } \\
\text { /Sauce / } & \rightarrow \text { / Sambalaq / }
\end{array}
$$

Phoneme / $1 /$ at the end of words in Indonesian when absorbed into the language of the Bugis turned into a glottal stop / q / as contained in the data (4). This is in accordance with the Proto South Sulawesi, because in Bugis there is no phoneme / $1 /$ at the end of the word.

5. Phoneme / d / at the end of words in Indonesian turn into glottal / q / in Bugis

Example:

$\begin{array}{ll}\text { /volume/ } & \rightarrow \text { / Jiliq / } \\ \text { /student/ } & \rightarrow \text { / Muriq / } \\ \text { /century/ } & \rightarrow \text { / Abaq / } \\ \text { /Sunday/ } & \rightarrow \text { / Ahaq / }\end{array}$

Phoneme / d / at the end of words in Indonesian when absorbed into the language of the Bugis turned into a glottal stop / q / as contained in the data (5). This is in accordance with the Proto South Sulawesi, because in Bugis there is no phoneme / $\mathrm{d} /$ at the end of the word.

6. Phoneme $/ \mathrm{k} /$ at the end of words in Indonesian turn into glottal / q / in Bugis

Example:

/ Cankok / $\rightarrow$ / Cankoq /
/ Mortar / $\rightarrow$ / Cobeq /
/ Gəmbok / $\rightarrow$ / Gəmboq /
/ Shake / $\rightarrow$ / Kocoq /

Phoneme / k / at the end of words in Indonesian when absorbed into the language of the Bugis turned into a glottal stop / q / as contained in the data (6). This is in accordance with the Proto South Sulawesi

7. Nasal phoneme / n, m/ at the end of words in Indonesian transformed into nasal / $\mathrm{y} /$ in Bugis.

Example:

/tree/ $\rightarrow$ /pound/

/wind/ $\rightarrow$ / Anin /

/midwife/ $\rightarrow$ /midwife/

/spinach/ $\rightarrow$ / Bayan /

Nasal phoneme / $\mathrm{n} /$ and / $\mathrm{m} /$ at the end of words in Indonesian transformed into nasal / $\mathrm{y} /$ in Bugis. This is in accordance with the Proto-South Sulawesi because the Bugis language there is no nasal phoneme $/ \mathrm{n} /$ and $/ \mathrm{m} /$ at the end of the word.

8. Phoneme / $\mathrm{o} /$ in the first syllable in Indonesian turn into geminasi in Bugis

Example:

/ Pedem /

/powder/

$$
\rightarrow \text { / Pəddəy / }
$$

/iron/

$\rightarrow$ / Boddaq /

/yarn/

$\rightarrow$ / Bassi /

$\rightarrow$ / Wonnay /

Phoneme / 2 / in the first syllable of patterned KV (consonant-vowel) in Indonesian when absorbed in Bugis turned into geminasi. It shows the characteristics of phonemes system in Bugis

9. Vowel phoneme / $\partial$ / in the first syllable in Indonesian turn into phonemes vowel / a / in Bugis

Example:

/ Bəlanak / $\rightarrow$ / Balanak /

/ Bəlanja / $\rightarrow$ / Balanca /

/ Bəlayko / $\rightarrow$ / Balayko /

/ Bəlanda / $\rightarrow$ / Balanda /

Indonesian words in which there phoneme / $\partial$ / in the first syllable when absorbed in Bugis turned into phonemes / a /, as shown in the data (9). In South Sulawesi unclear Proto symbolized phoneme / a /, only the phoneme / e /, but in the realization exist.

10. Phoneme / b / in Indonesian transformed into phoneme / $\mathrm{w} /$ in Bugis

Example:

$\begin{array}{ll}\text { /ash/ } & \rightarrow \text { / Awu / } \\ \text { /rice/ } & \rightarrow \text { / Borrə / - / wərrə / } \\ \text { /clothes/ } & \rightarrow \text { / Waju / } \\ \text { / Bold / } & \rightarrow \text { / Warani / }\end{array}$

Words in Indonesian beginning with the phoneme / b / when absorbed into the language of the Bugis transformed 
into phoneme / w /. Phoneme / b / and / w / in Proto Austronesian phoneme correspondence.

11. Phoneme / z / in Indonesian turn into phonemes / s / in Bugis

Example:

$$
\begin{array}{ll}
\text { /Bazaar / } & \rightarrow \text { / Bazaar / } \\
\text { /Charity / } & \rightarrow \text { / Səkkə / } \\
\text { /Zam Zam/ } & \rightarrow \text { / Sam-sam / } \\
\text { /Olive/ } & \rightarrow \text { / Saituy / }
\end{array}
$$

Phoneme / $\mathrm{z}$ / in words Indonesian when absorbed into the language of the Bugis change to phonemes / $\mathrm{s} /$. This is due in South Sulawesi Proto Austronesian there is no phoneme / $\mathrm{z} /$ in Bugis in all positions.

12. Phoneme / $\mathrm{h} /$ at the beginning of words in Indonesian dissolved in Bugis

Example:

$$
\begin{array}{ll}
\text { / Hajj / } & \rightarrow \text { / Aji / } \\
\text { / smooth } & \rightarrow \text { / Alusuq / } \\
\text { / heart } & \rightarrow \text { / Ati / } \\
\text { / Breathe / } & \rightarrow \text { / Iro / }
\end{array}
$$

If the phoneme / $\mathrm{h} /$ are at the beginning of words in Indonesian absorbed into the Bugis language, the phoneme / $\mathrm{h}$ / as contained in the data (12) melted. It happened because the phoneme / $\mathrm{h} /$ in proto South Sulawesi is not found in Bugis.

\section{CONCLUSION}

The results showed: (1) phonemes / p /, / t /, / d /, and / k / at the end of words in Indonesian turn into glottal / $\mathrm{q} / \mathrm{when}$ absorbed into the Bugis language. Likewise, the phoneme / s / and / 1 / sounds turn into glottal / q /. Only phoneme / s / and / 1 / phonemes that undergo additions; (2) phoneme /ə/ At the beginning of syllables turned into sound geminasi; (3) nasal phonemes $/ \mathrm{m} /$ and $/ \mathrm{n} /$ in Indonesian turn into phonemes nasal / $\mathrm{y} /$ when absorbed into the Bugis language; (4) nasal phoneme / $/ \mathrm{/}$ in Indonesian transformed into phoneme / a / when absorbed into the Bugis language; (5) phoneme / b / in Indonesian transformed into phoneme / w / when absorbed into the Bugis language; and (6)phoneme / z / in Indonesian turn into phonemes / s / when absorbed into the Bugis language; and (7) the phoneme / h / in Indonesian melted when absorbed in Bugis. Thus, it can be concluded that the sounds in Bugis absorbed from Indonesian to change the sound.

\section{References}

[1] J. N. Sneddon, The Indonesian language: Its history and role in modern society. UNSW Press Sydney, 2003.

[2] R. F. Mills, "Proto South Sulawesi and Proto Austronesian Phonology. Vol. I and II," Diss. Abstr. Int. A. Humanit. Soc. Sci., vol. 36, no. 6, 1975.

[3] J. Noorduyn, A critical survey of studies on the languages of Sulawesi, vol. 18. Kitlv Press, 1991.

[4] Ü. Sirk, The Buginese language. "Nauka" Pub. House, Central Dept. of Oriental Literature, 1983.
[5] A. Mackey and S. M. Gass, Second language research: Methodology and design. Routledge, 2015. 